REPORTS OF MORPHOLOGY
$\begin{gathered}\text { Official Journal of the Scientific Society of Anatomists, } \\ \text { Histologists, Embryologists and Topographic Anatomists } \\ \text { of Ukraine } \\ \text { journal homepage: https://morphology-journal.com }\end{gathered}$

\title{
Changes of the ultrastructural organization of cells of rats esophagus in the modeling of second-degree esophageal stricture
}

Shaprynskyi Ye.V.

National Pirogov Memorial Medical University, Vinnytsya, Ukraine

\section{ARTICLE INFO}

Received: 17 June, 2019

Accepted: 22 July, 2019

UDC: $616-001.37-089.844$

CORRESPONDING AUTHOR

e-mail: evgensh20078@gmail.com Shaprynskyi Ye.V.

\begin{abstract}
Scar strictures that lead to obstruction of the esophagus do not tend to decrease lately, but on the contrary, the number of such patients is increasing, which is caused by the use of a large range of chemicals in human life. The results of treatment of scarring strictures depend on the degree of stenosis. With complete obstruction of the esophagus, the question arises about conducting surgical treatment. Methods of correction of esophageal strictures have a considerable number of postoperative complications and lethal consequences - from $5.0 \%$ to $15.0 \%$. Therefore, in order to create a unified pathogenetic tactic for the management and treatment of esophageal strictures, we were offered to study the ultrastructural changes of the mucous membrane of the stricture of the second stage during its modeling in the experiment. The purpose of the work is to investigate the dynamics of ultrastructural changes of the mucous membrane of the esophagus wall in the normal and second stage of its stricture. The experimental study was performed on adult white male rats weighing between 250 and $300 \mathrm{~g}$. A total of 16 animals were operated on, which were divided into 2 groups: a control group (6 rats) and a study group (10 rats). The studies were performed under ketamine anesthesia. In animals of the control group performed only laparotomy, followed by layer-by-layer suturing of the anterior abdominal wall. In animals of the study group created a model of obstruction of the esophagus of the second stage. Electron microscopic examination was performed on days 3,4 , and 5 of the experiment, eliminating animals by overdosing on ketamine. As a result of the electron microscopic study of the ultrastructural organization of basal, spinosum, superficial epitheliocytes of stratified squamous epithelium without keratin, smooth muscle myocytes of the muscular plate and contractile elements of the muscular layer of the esophagus of rats with simulated stricture of the second degree revealed dystrophic and destructive disorders that varied in depth and severity. It was established that mitochondrial dysfunction leads to a decrease in the activity of reparative, metabolic and synthetic processes of the cell, which is indirectly manifested by a decrease in ribosomes and polysomes in the cytoplasm, loosening and focal lysis of membranes of the granular endoplasmic reticulum. Stricture of esophagus of the second stage causes activation of catabolic intracellular processes in all cells, which is morphologically confirmed by the appearance in the cytoplasm of secondary lysosomes and inclusions of lipids.

Keywords: esophageal cell ultrastructure, esophageal stricture, mitochondrial dysfunction.
\end{abstract}

\section{Introduction}

Scar strictures that lead to obstruction of the esophagus do not tend to decrease lately, but on the contrary, the number of such patients is increasing, which is caused by the use of a large range of chemicals in human life $[4,8$, $10,24,27,30]$. The results of treatment of scarring strictures depend on the degree of stenosis. In the first and second stage of esophageal obstruction it is possible to carry out dilatation therapy, with complete obstruction of the esophagus the question arises about conducting surgical treatment [2, 3, 5, 11, 16, 17, 25]. However, both dilatation and operative methods of correcting esophageal strictures still have a significant number of postoperative complications and lethal consequences - from $5 \%$ to $15 \%$ $[1,6,9,12,13,14,15,20,29]$. 
Therefore, in order to create a single pathogenetic tactic for the management and treatment of esophageal strictures, we were offered to study the ultrastructural changes of the mucous membrane of the stage of stricture of the second degree in its modeling in the experiment, which is most common in clinical practice [18, 19, 26].

The purpose of the work is to investigate the dynamics of ultrastructural changes of the mucous membrane of the esophagus wall in the normal and second stage of its stricture.

\section{Materials and methods}

The experimental study was performed on adult white rats, males weighing $250 \mathrm{~g}$ to $300 \mathrm{~g}$, in accordance with the general principles of animal experiments approved by the First National Congress on Bioethics (Kyiv, 2001) and in accordance with the provisions of the European Convention for the Protection of Vertebrate Animals used for experimental and other scientific purposes (Strasbourg, 1986).

A total of 16 animals were operated on, which were divided into two groups: control (6 rats) and studies (10 rats). Before the experiment began, animals were observed in the same conditions in the vivarium for a week. The studies were performed under ketamine anesthesia. In animals, the control group performed only laparotomy, followed by layerby-layer suturing of the anterior abdominal wall. On days 3 , 4,5 of the experiment, the animals were removed from the experiment by an overdose of ketamine and performed a relaparotomy to collect material for electron microscopic examination - the wall of the unchanged abdominal part of the esophagus. The animals of the study group created a model of second-degree esophageal obstruction as follows: performed a median laparotomy, isolated the abdominal esophagus, and then took the conductor from the adult subclavian catheter through the mouth into the stomach and tied the abdominal esophagus. Electron microscopic examination was performed on days 3,4 , and 5 of the experiment, eliminating animals by overdosing on ketamine. The material for electron microscopic examination was a section of the simulated stricture of the II degree of the esophagus wall of rats.

The method of preparation of the material was that for pre-fixation pieces of tissue after their collection was immediately immersed in $2.5 \%$ buffered solution glutaraldehyde retainer at a temperature of $4^{\circ} \mathrm{C}$. After treatment in the buffer solution, the tissue was transferred for final fixation in $1 \%$ buffered solution of osmium tetroxide for 3-4 hours, followed by dehydration in alcohols of increasing concentration and acetone. The fabric was placed in a mixture of epoxy resins according to conventional methods. The polymerization of the blocks was carried out in a thermostat at $60^{\circ} \mathrm{C}$ for two days. Sections were made from the blocks obtained using a UMTP-3M ultramicrotome, mounted on electrolytic grids and, after contrast with lead citrate, examined under an electron microscope EMV-100 $\mathrm{BR}$ at a voltage of $75 \mathrm{~kW}$. Quality control of histological processing of the material was performed using pieces of the mucous membrane of the abdominal esophagus of intact experimental animals.

\section{Results}

The study of the ultrastructural organization of the organs of cells of the mucous membrane of the esophagus of the control group of rats indicated the adequacy of the chosen method of histological tissue processing and met modern requirements.

In submicroscopic organization of basal cells of the mucous membrane of the wall of the esophagus of rats on the site of the second-stage simulated stricture, degenerative changes of organelles were combined with the foci of destruction of intracellular membranes. Nuclear chromatin in the basal epitheliocytes was in a condensed state, and its clusters were concentrated along the periphery of the nucleus matrix and evenly distributed along the slice plane. The nuclear membrane, except for the loosening cells, had lysis cells. Perinuclear spaces were moderately expanded. The nuclear matrix was highly enlightened. In the central region of the matrix were concentrated granules of decondensed chromatin. Tanks of the granular endoplasmic reticulum were greatly expanded and presented as vacuoles of various shapes and sizes, the contents of which were of low electron density. A small number of ribosomes are attached to the membranes of the granular endoplasmic reticulum. When compared with the control group in the cytoplasm was reduced the number of free ribosomes and the polysomes. Total destruction of the membranes of the granular endoplasmic reticulum in some basal epitheliocytes was observed, secondary lysosomes were detected in the cytoplasm (Fig. 1).

The mitochondria were of various shapes and sizes, moderately swollen. Their matrix had a rough structure with

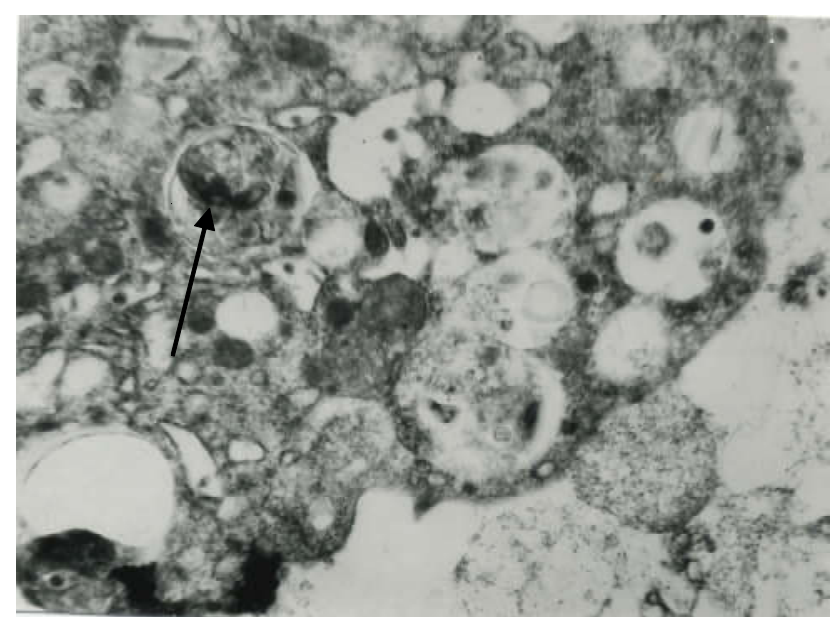

Fig. 1. Ultrastructure of basal epitheliocytes of stratified squamous epithelium without keratin with simulated second-degree stricture. Destruction of granular endoplasmic reticulum membranes, secondary lysosomes and lipid incorporation into the cytoplasm (arrow). x43000. 


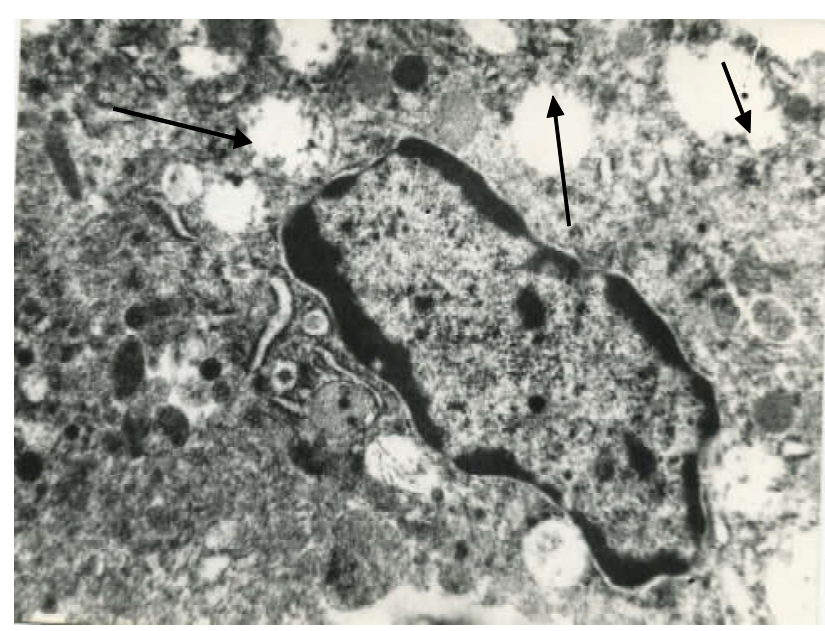

Fig. 2. Ultrastructure of basal epitheliocytes of stratified squamous epithelium without keratin with simulated second-degree stricture. Enlightenment of the matrix of mitochondria and destruction of the cristae (arrow). x43000.

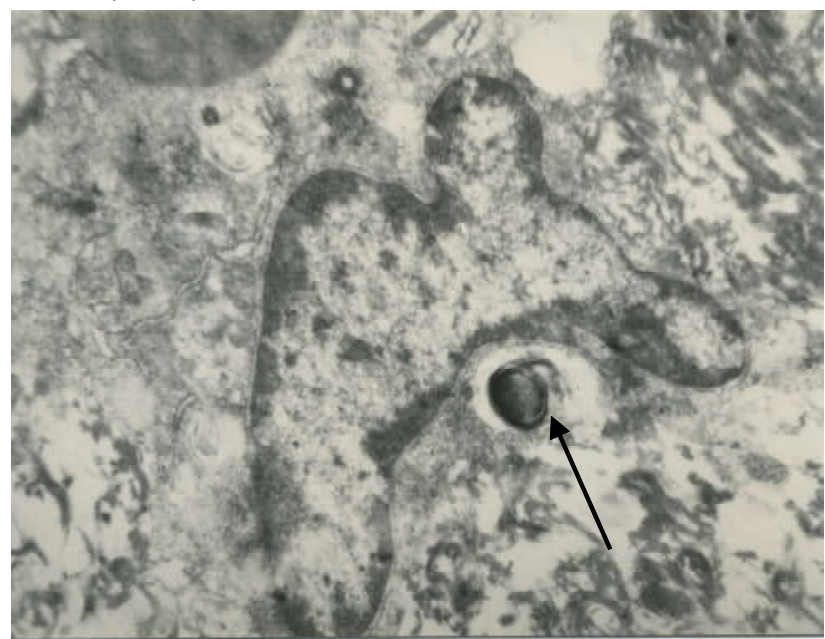

Fig. 3. Ultrastructure of basal epitheliocytes of stratified squamous epithelium without keratin with simulated second-degree stricture. Inclusion of lipids in the cytoplasm (arrow). x34000.

an average electron density. A small number of cristae in the mitochondria were disorganized and deformed, the outer membranes in some mitochondria and the cristae were lysed. Sometimes in the cytoplasm of basal epitheliocytes, mitochondria were present whose cristae were destroyed. Such mitochondria looked like electronically transparent vacuoles (Fig. 2).

The lamellar cytoplasmic Golgi complex was moderately reduced. The parallel orientation of the smooth membranes is impaired. A small number of small vacuoles were found in the location of the plate cytoplasmic Golgi complex. Sometimes the inclusion of lipids was detected in the cytoplasm (Fig. 3).

Violation of the parallel orientation of the tonofibrils was observed. Intercellular spaces remained enlarged. The spinosum epitheliocytes of the esophageal mucosa had a polygonal shape and contained a centrally located nucleus.

The nuclear membrane had deep invaginations, loose structure, and lysis cells. The nuclear matrix was finely granular with an average electron density. Nuclear chromatin was in a decondensed state and its granules were diffusely distributed along the plane of the nucleus slice. The mitochondria were swollen, containing an electron-transparent matrix and single cristae. The outer membranes and cristae of the mitochondria were loosened (Fig. 4).

In the cytoplasm there was a large number of paralleloriented tonofibrils and glycogen granules. Secondary lysosomes were sometimes found in the area of the plate cytoplasmic Golgi complex. Tanks of the granular endoplasmic reticulum were vacuolated, the membranes moderately loosened with lysis cells. Spinosum epitheliocytes with fragmented membranes of the granular endoplasmic reticulum were encountered. Free ribosomes and polysomes are extremely rare in the cytoplasm. Occasions of lipids and secondary lysosomes in the cytoplasm of the spinosum layer epitheliocytes were sometimes found. The intercellular spaces were greatly expanded. Cytoplasmic and intracellular membranes of superficial epitheliocytes are strongly thickened, loosened and osmiophilous.

In smooth muscle myocytes of the muscle plate and the muscle layer of the rat esophagus in the second-degree stricture, the ultrastructural organization had moderately pronounced dystrophic changes. Higher number of nuclear chromatin was in a decondensed state. Separate areas of the nuclear membrane were loosened. There were almost no foci of nuclear membrane lysis. Perinuclear spaces were uniformly expanded. The deformation of the nuclear membrane was observed in the form of its deep invaginations. The cytoplasmic membrane was strongly loosened with areas of lysis (Fig. 5).

The mitochondria had an electron-transparent matrix and contained a small number of shortened cristae. The

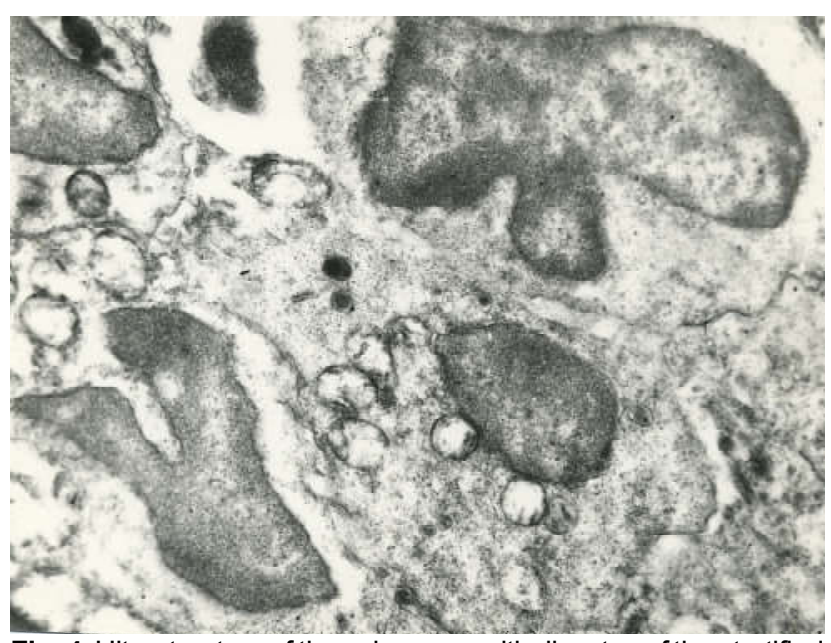

Fig. 4. Ultrastructure of the spinosum epitheliocytes of the stratified squamous epithelium without keratin with simulated second-degree stricture. Nuclear membrane invagination, matrix enlightenment and mitochondrial membrane lysis. x32000. 


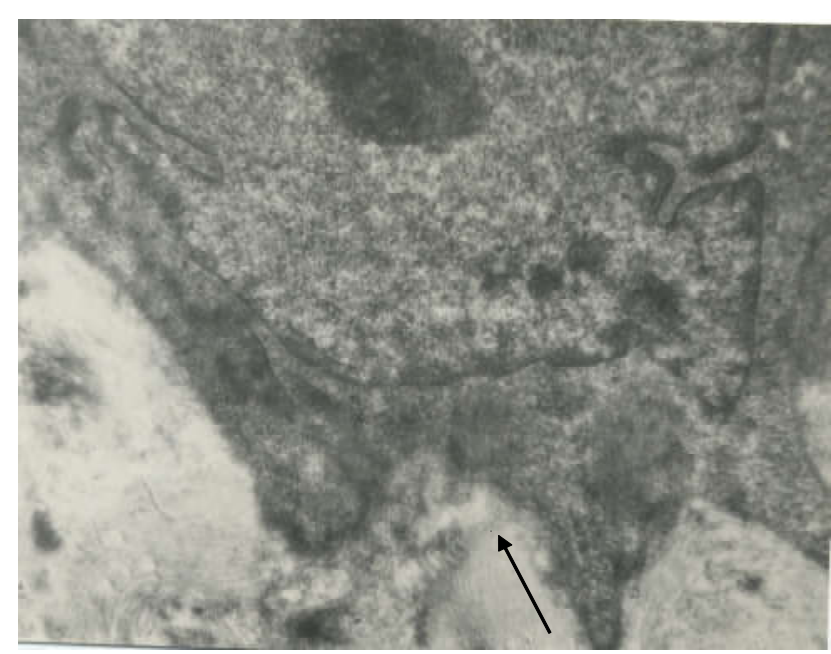

Fig. 5. Ultrastructure of smooth rat esophageal myocytes with modeled second-degree stricture. Nuclear membrane invagination, loosening and cytoplasmic membrane lysis (arrow). x32000.

sites of outer membrane lysis and mitochondrial cristae were relatively rare. The lamellar cytoplasmic Golgi complex was moderately reduced. Single micropinocytotic vesicles were detected near the cytoplasmic membrane.

In the ultrastructural organization of the endothelial cells of the blood capillaries, distinct dystrophic changes were determined in the stricture region. Endotheliocyte nuclei contained condensed chromatin diffusely scattered across the matrix. The nuclear membrane had multiple small invaginations. The mitochondria were small with an electron-transparent matrix and single cristae. Tanks of the granular endoplasmic reticulum were filled with electronically transparent material. In comparison with the group of intact animals, fewer ribosome-bound ribosomes were observed on the surface of the granular endoplasmic reticulum membranes in the animals of the study group. Free-standing ribosomes and polysomes are very rare. In the cytoplasm of the processes of endothelial cells of the blood capillaries were micropinocytotic vesicles.

\section{Discussion}

As a result of the electron microscopic study of the ultrastructural organization of basal, spinosum, superficial epitheliocytes of stratified squamous epithelium without keratin, smooth myocytes of the muscular plate and contractile elements of the muscular layer of the esophagus of rats with simulated stricture of the second degree revealed dystrophic and destructive disorders that varied in depth and severity. Unlike the first-degree stricture, as shown by Shaprynsky Y. V. et al. in 2013 [21], dystrophic and destructive disorders were more pronounced.

When the esophagus is completely obstructed, that is, in animals with a third-degree modeled stricture, destructive disorders prevail to a greater extent. Stein H. J. et al. (1995) and Shaprynsky Y. V. in 2016 confirmed the fact that the focal lysis was subject to a nuclear membrane, mitochondrial membrane, endoplasmic reticulum and lamellar cytoplasmic Golgi complex [22, 23].

The leading point in the development of these processes in the stratified squamous epithelium without keratin is mitochondrial dysfunction, which morphologically manifests focal destruction of the outer membranes and the cristae. Mitochondrial dysfunction leads to a decrease in the activity of the reparative, metabolic and synthetic processes of the cell, which is indirectly manifested by a decrease in ribosomes and polysomes in the cytoplasm, loosening and focal lysis of membranes of the granular endoplasmic reticulum. As shown in their works Shaprinsky Y. V. et al. [21] and Chandrasoma P.T. et al. [7], in animals with first-degree modeled stricture, there are deformations of the nuclear membrane, mitochondrial membranes, membranes of the granular endoplasmic reticulum and the lamellar cytoplasmic Golgi complex, which is explained by the inclusion of redundant intracellular mechanisms related to the phenomena of piezobiosynthesis. Cells under conditions of insufficient energy supply of metabolic processes use the piezoelectric energy, which occurs during deformation of membranes, which are liquid crystals. In the simulated stricture of the third degree, total lysis of membranes of the granular endoplasmic reticulum was sometimes observed [14, 22, 28].

Ultrastructural changes of smooth myocyte organelles and cross-striated muscle fibers in the region of the seconddegree esophageal stricture indicate a decrease in the contractile capacity of these cells. Submicroscopic disorders of the endothelial cells of the capillary bed of the esophagus are characterized by a decrease in the electron density of the cytoplasm due to the development of intracellular edema, the absence in the cytoplasm of appendages of endothelial cells of micropinocytosis vesicles, which is characteristic for the decrease in the activity of transcellular transport of substances, water and electrolytes up to its termination under the condition of modeling of the third-degree esophageal stricture [22]. That is, the organelles of smooth myocytes and skeleton muscles and endothelial cells of the esophageal capillary are undergoing similar changes.

The esophageal stricture of the second stage causes activation of catabolic intracellular processes of the mucous membrane epithelium, which is structurally confirmed by the appearance of secondary lysosomes in the cytoplasm and inclusions of lipids. With third-degree stricture, there is an even greater increase in catabolic processes, and the changes become irreversible [22]. And disturbances of submicroscopic architectonics of rat esophagus cells with simulated first-degree stricture are reversible after elimination of an external, negative factor [21].

In the future, we also plan to investigate the ultrastructural changes of esophageal cells in the dynamics after removal of the stricture.

\section{Conclusions}

1. It is established that in the area of the simulated stricture of the second degree, degenerative and destructive 
disorders of the ultrastructural organization of the epithelial cells of the stratified squamous epithelium without keratin, smooth muscle cells of the muscular plate and contractile elements of the muscular layer of the esophagus, which vary in degree and depth, develop.

2. Mitochondrial dysfunction is a major element in

\section{References}

[1] Andreeshchev, S.A., Myasoedov, S.D., Usenko, A. Yu. \& Movchan, B. B. (2008). Repeated operations on the artificial esophagus. Clinical surgery, 4-5.

[2] Boyko, V. V., Korolevska, A. Y., Savvi, S. O., Korolevska, A. Y., \& Zhidetsky, V. V. (2018). Features of surgical tactics at long scarring of esophagus. Clinical surgery, 85(1), 52-55.

[3] Boyko, V. V., Savvi, S. O., Lazirsky, V. O., \& Likhman, V. M. (2014). Artifical stomach: Gastric plastic is an ileocecal segment of the intestine. Kharkiv: Promin'.

[4] Boyko, V. V., Shaprinsky, V. O., \& Shaprinsky, E. V. (2015). Treatment of scarring of esophagus. Kharkov Surgical School, 73(4), 152-155.

[5] Cerfolio, R. J., Wei, B., Hawn, M. T., Minnich D. J. (2016). Robotic esophagectomy for cancer: early results and lessons learned. Semin. Thorac. Cardiovasc. Surg., 28(1), 160-169. doi: 10.1053/j.semtcvs.2015.10.006

[6] Chadi, S. A., Fingergut, A., Berho, M., DeMeester, S. R., Fleshman, J. W., Hyman, N. H. ... Wexner, S. D.. (2016). Emerging trends in the etiology, prevention and treatment of gastrointestinal anastomotic leakage. J. Gastrointest. Surg., 20(12), 20352051. doi: 10.1007/s11605-016-3255-3

[7] Chandrasoma, P. T., Der, R., Ma, Y., Peters, J., \& DeMeester, T. (2003). Histologic classification of patients based on mapping biopsies of the gastroesophageal junction. Am. J. Surg. Pathol., 27, 929-936.

[8] Iskit, S. H., Ozcelik, Z., Alkan, M., Türker, S., \& Zorludemir, U. (2014). Factors affecting the prevalence of gastrooesophageal reflux in childhood corrosive oesophageal strictures. Balkan Med. J., 31(2), 137-142. doi: 10.5152/ balkanmedj.2014.13276

[9] Kachmar, W. M. (2016). Esophageal ruptures, mediastinitis - an individual approach to treatment. Hospital surgery. Journal of the name of L.Y. Kovalchuk, 1, 116-117.

[10] Kim, S. H., Jeong, J. B., Kim, J. W., Koh, S. J., Kim, B. G., Lee, K. L. ... Shin, C. M. (2014). Clinical and endoscopic characteristics of drug-induced esophagitis. World $\mathrm{J}$. Gastroenterol. 20(31), 10994-10999.

[11] Lazirsky, V. A., Boyko, V. V., Kryvorotko, I. V. \& Savvi, S. A. (2014). The use of the ileocecal segment of bowel for reconstruction after combined gastrectomy. European Journal of Surgical Oncology, 40, 11, 156. doi: 10.1016/ j.ejso.2014.08.395

[12] Low, D. E., Alderson, D., Cecconello, I., Chang, A. C., Darling, G. E., D? Journo X. B. ... van Lanschot, J. J. (2015). International consensus of standardization of data collection for complications associated with esophagectomy: Esophagectomy Complications Consensus Group (ECCG). Ann. Surg., 262, 286-294.

[13] Melnyk, V. M., \& Poida, O. I. (2016). Surgical tactics for the failure of sutures of intestinal anastomoses. Clinical surgery, 6, 8-12.

[14] Mori, H., Koike, M., Gotow, T., Ichimura, K., Asaoka, D., Oguro, M. ... Watanabe, S. (2011). Ultrastructural analyses of the rat esophageal stratified epithelium under normal conditions and in chronic reflux esophagitis, Archives of Histology and reducing the activity of reparative, metabolic and synthetic intracellular processes.

3. The esophageal stricture of the second stage causes activation of catabolic intracellular processes in all cells, which is morphologically confirmed by the appearance in the cytoplasm of secondary lysosomes and lipid inclusions.

Cytology, 73(4-5), 199-214. doi: 10.1679/aohc.73.199

[15] Newton, N. J., Sharrock, A., Rickard, R., \& Mughal M. (2017). Systematic review of the use of endo-luminal topical negative pressure in oesophageal leaks and perforations. Dis. Esophagus, 30(3), 1-5. doi: 10.1111/dote.12531

[16] Perbtani, Y., Suarez, A. L., \& Wagh, M. S. (2016). Emerging techniques and efficacy of endoscopic esophageal reconstruction and lumen restoration for complete esophageal obstruction. Endosc. Int. Open., 4(2), 136-142. doi: 10.1055/ s-0041-107898.

[17] Reavis K. M. (2009). The esophageal anastomosis: how improving blood supply affects leak rate. J. Gastrointest. Surg., 13, 1558-1560. doi: 10.1007/s11605-009-0906-7

[18] Savvi, S. A., \& Nevzorova, O. V. (2009). The clinical significance of ultrastructural changes in the esophagus after a chemical burn. International Medical Journal, 27(2), 73-74.

[19] Sarkisov, D. S., \& Perov, Yu. L. (1996). Microscopic technique. Leadership. Moscow: Medicine.

[20] Senyutovich, R. V., Barannikov, K. V., Bodiak, V. Y., Shumko, B. I., Unguryan, V. P., \& Chorny, O. V. (2016). Stapler esophageal anastomosis. Current trends. Hospital surgery. Journal of the name of L.Y. Kovalchuk, 2, 103-107. Режим доступу: http://nbuv.gov.ua/UJRN/shpkhir_2016_2_26

[21] Shaprynskyi, E. V., Nevzorov, V. P., \& Nevzorova, A. F. (2013). Violation of the ultrastructure of esophageal cells with simulated esophageal stricture in experiment. Bulletin of problems of biology and medicine, 2(105), 4, 226-230.

[22] Shaprynskyy, Ye. V. (2016). Changes in the ultrastructural organization of cells of the mucous membrane of the esophagus of rats with simulated third-degree stricture. Clinical anatomy and surgery, 15(3), 6-10.

[23] Stein, H. J., Liebermann-Meffert, D., DeMeester, T. R., \& Siewert, J.R. (1995). Threedimensional pressure image and muscular structure of the human lower esophageal sphincter. Surgery, $117,692-698$

[24] Shafa, S., Sharma, N., Keshishian, J., \& Dellon, E. S. (2016). The black esophagus: a rare but deadly disease. ACG Case Rep J., 3(2), 88-91. doi: 10.14309/crj.2016.9

[25] Swanson, E. W., Swanson, S. J., \& Swanson R. S. (2012). Endoscopic pyloric balloon dilatation obviates the need for pyloroplasty at esophagectomy. Surg. Endosc., 26(7), 20232028. doi: 10.1007/s00464-012-2151-5

[26] Tertychny, A. S., Mamchenko, S. I., \& Dubrovskaya, M. I. (2014). Morphological characteristics of the mucous membrane of the esophageal-gastric transition zone in children with gastroesophageal reflux disease. Experimental and clinical gastroenterology, 1, 30-34

[27] Usenko, A. Yu., Lavrik, A. S., Andreeshchev, S. A., Movchan, B. B., \& Doskuch, O. A. (2010). Comparative evaluation of various types of total and subtotal esophagoplasty. AllUkrainian scientific-practical conference with international participation "Modern problems of breast surgery". Kharkov: Promin'.

[28] Weickert, U., Wolf, A., Schröder, C., Autschbach, F., Vollmer, H. (2011). Frequency, histopathological findings, and clinical 
significance of cervical heterotopic gastric mucosa (gastric inlet patch ): a prospective study in 300 patients. Dis. Esophagus, 24, 63.

[29] Worrell, S., Mumtaz, S., Tsuboi, K., Lee, T. H., \& Mittal, S. K. (2010). Anastomotic complications associated with stapled versus hand-sewn anastomosis. J. Surg. Res., 161(1), 9-12. doi: 10.1016/j.jss.2009.07.004

[30] Zhang, D. H., Zhou, L. Y., Dong, X. Y., Cui, R. L., Xue, Y., \& Lin, S. R. (2010). Factors influencing intercellular spaces in the rat esophageal epithelium. World J. Gastroenterol., 16, 10631069. doi: 10.3748/wjg.v16.19.1063

\section{ЗМІНИ УЛЬТРАСТРУКТУРНОЇ ОРГАНІЗАЦІЇ КЛІТИН СТРАВОХОДУ ЩУРІВ ПРИ МОДЕЛЮВАННІ СТРИКТУРИ СТРАВОХОДУ ДРУГОГО СТУПЕНЯ \\ Шапринський $\Theta . B$.}

Рубцеві стриктури, що призводять до непрохідності стравоходу, останнім часом не мають тенденції до зменшення, а навпаки, кількість таких хворих збільшується, що зумовлено використанням великого спектру хімічних речовин у побуті людини. Результати лікування рубцевих стриктур залежать від ступеня стенозування. При повній непрохідності стравоходу постає питання про проведення оперативного лікування. Методи корекції стриктур стравоходу мають значну кількість післяопераційних ускладнень і летальних наслідків - від 5,0 \% до 15,0%. Тому для створення єдиної патогенетичної тактики ведення і лікування стриктур стравоходу нами було запропоноване дослідження ультраструктурних змін слизової оболонки ділянки стриктури II ступеня при ї̈ моделюванні в експерименті. Мета роботи - дослідити динаміку ультраструктурних змін слизової оболонки стінки стравоходу в нормі та при другому ступені їі стриктури. Експериментальне дослідження проводили на статевозрілих білих щурах-самцях, масою від 250 до 300 г. Всього було прооперовано 16 тварин, котрих розподілили на 2 групи: контрольну групу (6 щурів) і групу дослідження (10 щурів). Дослідження проводили під кетаміновим наркозом. У тварин контрольної групи виконували тільки лапаротомію з подальшим пошаровим ушиванням передньої черевної стінки. У тварин групи дослідження створювали модель непрохідності стравоходу другого ступеня. Забір матеріалу для електронно-мікроскопічного дослідження виконували на 3, 4 та 5 добу експерименту, виводячи тварин иляхом передозування кетаміну. В результаті проведеного електронно-мікроскопічного дослідження ультраструктурної організації базальних, шипуватих, поверхневих епітеліоцитів багатошарового незроговілого епітелію, гладеньких міоцитів м'язової пластинки і скорочувальних елементів м'язового шару стравоходу щурів з модельованою стриктурою другого ступеня виявлено дистрофічні та деструктивні порушення, які варіювали за глибиною та ступенем виразності. Встановлено, що мітохондріальна дисфункція призводить до зниження активності репаративних, метаболічних та синтетичних процесів клітини, що опосередковано проявляється зменшенням кількості рибосом і полісом у цитоплазмі, розпушенням і вогнищевим лізисом мембран гранулярного ендоплазматичного ретикулума. Стриктура стравоходу другого ступеню викликає активацію катаболічних внутрішньоклітинних процесів у всіх клітинах, що морфологічно підтверджується появою у цитоплазмі вторинних лізосом та включень ліпідів.

Ключові слова: ультраструктура клітин стравоходу, стриктура стравоходу, мітохондріальна дисфуннція.

\section{ИЗМЕНЕНИЯ УЛЬТРАСТРУКТУРНОЙ ОРГАНИЗАЦИИ КЛЕТОК ПИЩЕВОДА КРЫС ПРИ МОДЕЛИРОВАНИИ СТРИКТУРЫ ПИЩЕВОДА ВТОРОЙ СТЕПЕНИ \\ Шапринский Е.В.}

Рубцовые стриктуры, которые приводят к непроходимости пищевода, в последнее время не имеют тенденции к уменьщению, а наоборот, количество таких больных увеличивается, что обусловлено использованием большого спектра химических веществ в быту человека. Результаты лечения рубцовых стриктур зависят от степени стенозирования. При полной непроходимости пищевода встает вопрос о проведении оперативного лечения. Методы коррекции стриктур пищевода имеют значительное количество послеоперационных осложнений и летальных последствий - от 5,0 \% до 15,0 \%. Поэтому, для образования единой патогенетической тактики ведения и лечения стриктур пищевода нами было предложено исследование ультраструктурных изменений слизистой оболочки участка стриктуры II степени при ее моделировании в эксперименте. Цель работы - исследовать динамику ультраструктурных изменений слизистой оболочки стенки пищевода в норме и при второй степени ее стриктуры. Экспериментальные исследования проводили на половозрелых белых крысахсамцах, массой от 250 до 300 г. Всего было прооперировано 16 животных, которых разделили на 2 группы: контрольную группу (6 крыс) и группу исследования (10 крыс). Исследования проводили под кетаминовым наркозом. Уживотных контрольной группы выполняли только лапаротомию с последующим послойным ушиванием передней брюшной стенки. У животных группы исследования создавали модель непроходимости пищевода второй степени. Забор материала для электронномикроскопического исследования выполняли на 3, 4 и 5 сутки эксперимента, выводя животных путем передозировки кетамина. В результате проведенного электронно-микроскопического исследования ультраструктурной организации базальных, шиповатых, поверхностных эпителиоцитов многослойного неороговевающего эпителия, гладких миоцитов мышечной пластинки и сократительных элементов мышечного слоя пищевода крыс с моделируемой стриктурой второй степени обнаружены дистрофические и деструктивные нарушения, которые варьировали по глубине и степени выраженности. Установлено, что митохондриальная дисфункция приводит к снижению активности репаративных, метаболических и синтетических процессов клетки, косвенно проявляется уменьшением количества рибосом и полисом в цитоплазме, разрыхлением и очаговым лизисом мембран гранулярного эндоплазматического ретикулума. Стриктура пищевода второй степени активизирует катаболические внутриклеточные процессы, что морфологически подтверждается появлением в цитоплазме клеток вторичных лизосом и включений липидов.

Ключевые слова: ультраструктура клеток пищевода, стриктура пищевода, митохондриальная дисфункция. 